\title{
The insertion/deletion polymorphism in the $A C E$ gene and chronic obstructive pulmonary disease
}

\author{
S. Simsek ${ }^{1}$, S. Tekes ${ }^{1}$, D. Oral ${ }^{1}$, A. Turkyilmaz ${ }^{1}$, B. Isik ${ }^{2}$, M.R. Isik ${ }^{3}$ and \\ H. Akkoc ${ }^{4}$ \\ ${ }^{1}$ Department of Medical Biology and Genetics, Medical Faculty, \\ Dicle University, Diyarbakir, Turkey \\ ${ }^{2}$ Department of Biochemistry, Medical Faculty, Dicle University, \\ Diyarbakir, Turkey \\ ${ }^{3}$ Department of Chest Diseases and Tuberculosis, Medical Faculty, \\ Dicle University, Diyarbakir, Turkey \\ ${ }^{4}$ Department of Pharmacology, Medical Faculty, Dicle University, \\ Diyarbakir, Turkey
}

Corresponding author: S. Simsek

E-mail: seldatsimsek@gmail.com

Genet. Mol. Res. 12 (2): 1392-1398 (2013)

Received September 13, 2012

Accepted February 15, 2013

Published April 25, 2013

DOI http://dx.doi.org/10.4238/2013.April.25.10

\begin{abstract}
An insertion/deletion (I/D) polymorphism was identified in intron 16 of the gene encoding the human angiotensin I-converting enzyme (ACE), a candidate gene for chronic obstructive pulmonary disease (COPD). We investigated the relationship between this polymorphism in the $A C E$ gene and the risk of developing COPD. Sixty-six COPD in-patients and 40 non-smoking control individuals were recruited for this study. The distribution of ACE genotypes in these individuals was studied. The frequencies of ACE genotypes were found to be $47.0 \%$ for DD, $30.3 \%$ for ID, and $22.7 \%$ for II in the COPD group and $32.5 \%$ for DD, $47.5 \%$ for ID, and $20.0 \%$ for II in the control group. The allele frequencies were found to be $0.62 \%$ for the D allele and $0.38 \%$ for the I allele in the COPD group and $0.56 \%$ for the $\mathrm{D}$ allele and $0.44 \%$ for the I allele in the control group. A significant difference
\end{abstract}


was found between I and $\mathrm{D}$ allele frequencies $(\mathrm{P}<0.05)$ of the study and control groups. Our results suggest that this ACE polymorphism may be associated with the development of COPD.

Keys words: $A C E$ gene; Chronic obstructive pulmonary disease; Polymorphism

\section{INTRODUCTION}

Chronic obstructive pulmonary disease (COPD) represents one of the most frequently occurring diffuse lung diseases and is influenced by both genetic and environmental factors (Ahsan et al., 2004). The World Health Organization lists COPD as the 5th most common cause of death, constituting approximately $5 \%$ of the total deaths in 2003 . This number is expected to rise in the near future with the current increase in tobacco consumption in the third world being of major concern (Lee et al., 2009; Selahaddin et al., 2010).

It is known that oxidative stress is increased in COPD patients compared with either healthy subjects or smokers with similar smoking history but who have not developed COPD (MacNee, 2005; Mak, 2008; Selahaddin et al., 2010). Angiotensin I-converting enzyme (ACE), a key enzyme in the renin-angiotensin system (RAS), plays an important role in the regulation of blood pressure and serum electrolyte levels (Berdeli and Cam, 2009; Zhang et al., 2011). ACE is a component of the systemic and tissue RAS, which play an important role in the regulation of blood pressure, sodium and water homeostasis, and tissue growth. The local RAS is found in a variety of tissues, including lung and skeletal muscle, and has a diverse range of functions that are often distinct from those of the systemic RAS (Zhang et al., 2008). Functional genetic polymorphic variants have been identified in most of the components of RAS, of which the best known and studied is a polymorphism in the $A C E$ gene.

The human $A C E$ gene is located on chromosome $17 \mathrm{q} 23$, spans $21 \mathrm{~kb}$, and comprises 26 exons and 25 introns (Berdeli and Cam, 2009; Zhang et al., 2011). The most widely studied polymorphism, an insertion/deletion (I/D, rs4646994), is located in intron 16. This polymorphism is characterized by the presence [insertion (I)] or absence [deletion (D)], in the intron, of a 287-bp nonsense DNA domain, resulting in 3 genotypes (II, DI, and DD) at this locus. The I/D polymorphism accounts for 20 to $50 \%$ of the variance in ACE expression or activity in blood and tissues among individuals (Rigat et al., 1992; Busquets et al., 2007; Zhang et al., $2008,2011)$. ACE activity is consistently the highest in DD subjects, intermediate in ID subjects, and the lowest in II subjects (Brice et al., 1995; Ucar et al., 1997; Busquets et al., 2007; Zhang et al., 2008).

Numerous studies have been published investigating the association of the $A C E \mathrm{I} / \mathrm{D}$ polymorphism with various pathophysiological conditions (Yaren et al., 2006, 2007; Gurkan et al., 2009; Namazi et al., 2010; Domingues et al., 2010; Yakut et al., 2010; Bayram et al., 2011; Zhang et al., 2011; Indrajaya, 2011; Hocher et al., 2011; Borzyszkowska et al., 2012). Molecular epidemiology studies showed that $A C E$ gene polymorphisms are closely associated with pulmonary disorders (Ahsan et al., 2004; Zhang et al., 2008). We examined the prevalence of the $A C E \mathrm{I} / \mathrm{D}$ polymorphism in COPD patients.

The aim of our study was to determine whether the $A C E$ gene I/D polymorphism can determine the course of COPD. 


\section{MATERIAL AND METHODS}

\section{Diagnosis of COPD}

All pulmonary function testing was performed according to the criteria of the American Thoracic Society/European Respiratory Society task force on the standardization of lung function testing (Miller et al., 2005a,b) using the same spirometer. Three technically acceptable measurements were taken from each patient, and the highest value was included in the analyses. We performed spirometric assessments on all subjects and early reversibility testing on those who had forced expiratory volume/forced vital capacity (FEV1/FVC) $<70 \%$.

The diagnosis of COPD in subjects with symptoms compatible with COPD was made when post-bronchodilator FEV1/FVC was less than 0.7. COPD was diagnosed in accordance with the Global Initiative for Chronic Obstructive Lung Disease (GOLD) guidelines (Marc et al., 2012).

\section{Subjects and controls}

Blood samples were collected from 66 COPD in-patients (42 males and 24 females; mean age: 61.23 years; SD: 11.41 years) and from 40 non-smokers (control group; 29 males and 11 females; mean age: 59.17 years; SD: 11.23 years), who were admitted to the Department of Chest Diseases and Tuberculosis, Faculty of Medicine, Dicle University. Control groups were drawn from the same population as that of the COPD subjects. This study was conducted in accordance with the Helsinki Declaration. As a standard procedure, an informed consent was obtained from each participant.

\section{Genotyping}

Genomic DNA was extracted from peripheral blood leukocytes by standard methods. The I/D polymorphism of the $A C E$ gene was genotyped as previously described (Rigat et al., 1992). The I/D polymorphism was amplified from genomic DNA by polymerase chain reaction (PCR) with the primers 5'-CTG GAG ACC ACT CCC ATC CTT TCT-3' and 5'-GAT GTG GCC ATC ACA TTC GTC AGA T-3'. PCR analysis was carried out in a final volume of 50 $\mu \mathrm{L}$ containing $10 \mathrm{pmol}$ of each primer at $25 \mathrm{pmol}, 2 \mathrm{mM}$ of each $4 \mathrm{dNTPs}, 50 \mathrm{mM} \mathrm{KCl}, 100$ mM Tris- $\mathrm{HCl}, \mathrm{pH} \mathrm{8.8,} 25 \mathrm{mM} \mathrm{MgCl}$, and $1 \mathrm{U}$ Taq Polymerase enzyme (MBI Fermentas, Germany) using a DNA thermal cycler (Techne PHC3 thermal cycler, UK). Thermal cycling was carried out using the following steps: 1 cycle at $94^{\circ} \mathrm{C}$ for 3 min followed by 35 cycles of $94^{\circ} \mathrm{C}$ for $1 \mathrm{~min}, 57^{\circ} \mathrm{C}$ for $1 \mathrm{~min}$, and $72^{\circ} \mathrm{C}$ for $1 \mathrm{~min}$. Final elongation included 1 cycle at $72^{\circ} \mathrm{C}$ for $10 \mathrm{~min}$. PCR products were analyzed by electrophoresis with a $2 \%$ agarose gel and visualized with ethidium-bromide staining. The insertion allele (I) was detected as a 490-bp band and the deletion allele (D) as a 190-bp band.

Under some conditions, the $A C E \mathrm{D}$ allele amplified more effectively than the longer I allele, resulting in mistyping of the ID genotype as DD (Ueda et al., 1996; Kanazawa et al., 2002). To address this, the sense primer used in the PCR was replaced with an insertionspecific primer that lead to the selective amplification of the I allele, which could now be detected in previously mistyped ID genotypes. Thus, all DD genotypes were reconfirmed. For I allele-specific PCR amplification, the following primer pair was used: 5'-TGG GAC CAC 
AGC GCC CGC CAC TAC-3' and 5'-TCG CCA GCC CTC CCA TGC CCA TAA-3'. Thermal cycling with this primer pair was carried out under the following conditions: 1 cycle at $94^{\circ} \mathrm{C}$ for $10 \mathrm{~min}$ followed by 30 cycles of $94^{\circ} \mathrm{C}$ for $30 \mathrm{~s}, 67^{\circ} \mathrm{C}$ for $30 \mathrm{~s}$, and $72^{\circ} \mathrm{C}$ for $30 \mathrm{~s}$. The final elongation step was 1 cycle at $72^{\circ} \mathrm{C}$. The PCR products were resolved by electrophoresis on a $2 \%$ agarose gel; the resulting 335-bp DNA fragment was stained with ethidium bromide and visualized. Only the I allele produced a 335-bp fragment, while no products were detected with the DD genotype. This confirmed the absence of mistyping. No mistyping was identified.

\section{Statistical analysis}

The data were analyzed using the Mann-Whitney U-test. Allele and genotype frequencies of the I/D polymorphism of the $A C E$ gene were obtained by direct counting. HardyWeinberg equilibrium was evaluated using the chi-square test. $\mathrm{P}<0.05$ was considered as significant. Statistical analyses were carried out using the statistical packages of SPSS 12.0 for Windows (SPSS Inc., USA).

\section{RESULTS}

We studied 66 in-patients with COPD and 40 non-smoking healthy control subjects. The main characteristics of the study subjects are shown in Table 1. The FEV1 value and the FEV1/FVC ratio of the COPD group were less than those of the control group $(\mathrm{P}<0.001)$. The male/female ratio was similar in all groups. The genotype and allele frequencies of the $A C E$ I/D polymorphism in COPD patients and in control groups are shown in Table 2. The $A C E$ genotype was determined by PCR.

\begin{tabular}{|c|c|c|c|}
\hline & COPD patients $(\mathrm{N}=66)$ & Non-smoker control group $(\mathrm{N}=40)$ & $\mathrm{P}$ \\
\hline Age (years) & $61.23 \pm 11.41$ & $59.70 \pm 11.23$ & \\
\hline Gender (male/female) & $42 / 24$ & $29 / 11$ & \\
\hline Pack/years smoking* & $55.12 \pm 12.14$ & - & \\
\hline FEV1 (\% predicted)* & $36.20 \pm 14.04$ & $78.50 \pm 10.60$ & $\mathrm{P}<0.001 * *$ \\
\hline FEV1/FVC (\% predicted)* & $62.80 \pm 7.35$ & $82.44 \pm 8.7$ & $\mathrm{P}<0.001 * *$ \\
\hline
\end{tabular}
and control groups.

Table 2. Genotype and allele frequencies of the I/D polymorphism in the $A C E$ gene.
\begin{tabular}{lccc}
\hline ACE I/D genotype & COPD patients (N $=66)$ & Non-smoker control group $(\mathrm{N}=40)$ & $\mathrm{P}$ \\
\hline DD & $31(47.0 \%)$ & $13(32.5 \%)$ & $\mathrm{P}>0.05$ \\
ID & $20(30.3 \%)$ & $19(47.5 \%)$ & $\mathrm{P}<0.05$ \\
II & $15(22.7 \%)$ & $8(20.0 \%)$ & $\mathrm{P}>0.05$ \\
Alleles & $82(0.62 \%)$ & $45(0.56 \%)$ & $\mathrm{P}>0.05$ \\
D & $50(0.38 \%)$ & $35(0.44 \%)$ & $\mathrm{P}>0.05$ \\
I
\end{tabular}

Data are reported as number with percent in parentheses.

The frequencies of $A C E \mathrm{I} / \mathrm{D}$ genotypes were found to be $47.0 \%$ for DD, $30.3 \%$ for ID, and $22.7 \%$ for II in COPD patients and $32.5 \%$ for DD, $47.5 \%$ for ID and $20.0 \%$ for II in the 
control group (Table 2). Allele frequencies were found to be $0.62 \%$ for the D allele and $0.38 \%$ for the I allele in COPD patients and $0.56 \%$ for the D allele and $0.44 \%$ for the I allele in the control group (Table 2).

The DD and II genotypes occurred at similar frequencies in COPD and control groups with no significant differences between them $(\mathrm{P}>0.05)$, while a significant difference was found between the I/D allele frequencies $(\mathrm{P}<0.05)$ of study and control groups (Table 2$)$.

\section{DISCUSSION}

Previous studies showed an association between $A C E$ genotypes and several phenotypic characteristics of COPD. Busquets et al. (2007) showed that the DD genotype was associated with an increased risk of a smoker developing COPD and, unexpectedly, that the ID genotype is more prevalent in individuals that smoke.

Kanazawa et al. (2002) investigated the association between $A C E$ polymorphisms and tissue oxygenation during exercise in patients with COPD and concluded that the $A C E$ DD genotype might be associated with a disturbance in peripheral tissue oxygenation during exercise in patients with COPD.

Zhang et al. (2008) reported an association between the $A C E$ gene polymorphism and exercise ventilatory response and skeletal muscle aerobic work efficiency in COPD patients. Their study indicates that the $A C E$ gene may be involved in the regulation of skeletal muscle aerobic work efficiency, but is not associated with exercise ventilatory responses in COPD patients.

Lee et al. (2009) investigated the relationship between elevated ACE activity and asthma, COPD, and COPD co-morbidity and found no association between the $A C E \mathrm{I} / \mathrm{D}$ genotypes and the risk of asthma or COPD. The $A C E$ I/D genotype was not associated with a higher prevalence of ischemic heart disease or hypertension in COPD patients. Likewise, the level of physical activity among COPD patients showed no correlation with their $A C E$ genotype. These data suggest that lifelong genetically elevated ACE activity is not a risk factor for asthma, COPD, or COPD co-morbidity (Lee et al., 2009).

Ahsan et al. (2004) investigated the correlation between $A C E$ polymorphisms and ACE and nitric oxide levels to explore a possible genotype-phenotype association. ACE levels increased and nitric oxide levels decreased with each copy of the $\mathrm{D}$ allele. The genotype combination of II was significantly greater in controls as compared to COPD patients $(\mathrm{P}=0.01$; odds ratio $=2.43 ; 95 \%$ confidence interval $=1.21-4.87$; relative risk $=2.00,1.15-3.48)($ Ahsan et al., 2004).

Hopkinson et al. (2004) investigated the relationship between the severity of skeletal muscle weakness in COPD and $A C E$ genotype. They showed that in COPD patients, the D allele was associated with greater quadriceps strength compared with the I allele, and the authors suggested that this may also apply for exercise capacity (Hopkinson et al., 2004). To address this hypothesis, it is important that future studies undertake the assessment of both muscle strength and endurance in combination with muscle biopsy analysis of fiber types (Harry et al., 2004).

Kanazawa et al. (2000) suggested that the I/D polymorphism in the $A C E$ gene may be associated with pulmonary hypertension evoked by exercise challenge in patients with COPD. Similarly, Tkacova et al. (2005) noted that increases in pulmonary artery pressure in patients with COPD are related to the $A C E \mathrm{I} / \mathrm{D}$ polymorphism.

Pabst et al. (2009) noted that the ACE I allele determines a stable course of COPD. 
The I allele was significantly associated with an increased risk for COPD in a dominant model, but not in a recessive or co-dominant model. Moreover, the I allele was more frequent in patients with a stable course of COPD $(\mathrm{P}=0.012)$ than in controls. In a dominant model (II/ ID $v s$ DD) they found an even stronger association between the I allele and a stable course of COPD. We also found significant differences in the I and D allele frequencies $(\mathrm{P}<0.05)$ in the study and control groups.

Our results suggest that $A C E$ polymorphisms may be associated with developing COPD. Further studies in large groups of patients with COPD are needed to address the role of $A C E$ polymorphisms in COPD in more detail.

\section{REFERENCES}

Ahsan A, Ram R, Baig MA and Pasha MA (2004). ACE I allele and eNOS G allele crosstalk may have a role in chronic obstructive pulmonary disease. Clin. Biochem. 37: 1037-1040.

Bayram B, Kilicci C, Onlu H, Ozkurt M, et al. (2011). Association of angiotensin converting enzyme (ACE) gene I/D polymorphism and polycystic ovary syndrome (PCOS). Gene 489: 86-88.

Berdeli A and Cam FS (2009). Prevalence of the angiotensin I converting enzyme gene insertion/deletion polymorphism in a healthy Turkish population. Biochem. Genet. 47: 412-420.

Borzyszkowska J, Stanislawska-Sachadyn A, Wirtwein M, Sobiczewski W, et al. (2012). Angiotensin converting enzyme gene polymorphism is associated with severity of coronary artery disease in men with high total cholesterol levels. J. Appl. Genet. 53: 175-182.

Brice EA, Friedlander W, Bateman ED and Kirsch RE (1995). Serum angiotensin-converting enzyme activity, concentration, and specific activity in granulomatous interstitial lung disease, tuberculosis, and COPD. Chest 107: 706-710.

Busquets X, MacFarlane NG, Heine-Suner D, Morla M, et al. (2007). Angiotensin-converting-enzyme gene polymorphisms, smoking and chronic obstructive pulmonary disease. Int. J. Chron. Obstruct. Pulmon. Dis. 2: 329-334.

Domingues-Montanari S, Fernandez-Cadenas I, del Rio-Espinola A, Mendioroz M, et al. (2010). The I/D polymorphism of the ACE1 gene is not associated with ischaemic stroke in Spanish individuals. Eur. J. Neurol. 17: 1390-1392.

Gurkan A, Emingil G, Saygan BH, Atilla G, et al. (2009). Angiotensin-converting enzyme (ACE), angiotensinogen (AGT), and angiotensin II type 1 receptor (AT1R) gene polymorphisms in generalized aggressive periodontitis. Arch. Oral Biol. 54: 337-344.

Harry RG, Herman-Jan P, Ann Emil MWJS, Nicholas SH, et al. (2004). ACE gene polymorphism in COPD. Am. J. Respir. Crit. Care Med. 170: 572-573.

Hocher B, Schlemm L, Haumann H, Jian L, et al. (2011). Offspring sex determines the impact of the maternal ACE I/D polymorphism on maternal glycaemic control during the last weeks of pregnancy. J. Renin-Angiotensin-Aldosterone Syst. 12: 254-261.

Hopkinson NS, Nickol AH, Payne J, Hawe E, et al. (2004). Angiotensin converting enzyme genotype and strength in chronic obstructive pulmonary disease. Am. J. Respir. Crit. Care Med. 170: 395-399.

Indrajaya T (2011). The role of ACE gene polymorphism on pathogenesis of ischemic stroke. Acta Med. Indones. 43: 152-157.

Kanazawa H, Okamoto T, Hirata K and Yoshikawa J (2000). Deletion polymorphisms in the angiotensin converting enzyme gene are associated with pulmonary hypertension evoked by exercise challenge in patients with chronic obstructive pulmonary disease. Am. J. Respir. Crit. Care Med. 162: 1235-1238.

Kanazawa H, Otsuka T, Hirata K and Yoshikawa J (2002). Association between the angiotensin-converting enzyme gene polymorphisms and tissue oxygenation during exercise in patients with COPD. Chest 121: 697-701.

Lee J, Nordestgaard BG and Dahl M (2009). Elevated ACE activity is not associated with asthma, COPD, and COPD comorbidity. Respir. Med. 103: 1286-1292.

MacNee W (2005). Pulmonary and systemic oxidant/antioxidant imbalance in chronic obstructive pulmonary disease. Proc. Am. Thorac. Soc. 2: 50-60.

Mak JC (2008). Pathogenesis of COPD. Part II. Oxidative-antioxidative imbalance. Int. J. Tuberc. Lung Dis. 12: 368-374. Marc D, Janssens W and Miravitles M (2012). Chronic obstructive pulmonary disease. Semin. Lancet. 379: 1341-1351.

Miller MR, Crapo R, Hankinson J, Brusasco V, et al. (2005a). General considerations for lung function testing. Eur. Respir. J. 26: 153-161. 
Miller MR, Hankinson J, Brusasco V, Burgos F, et al. (2005b). Standardisation of spirometry. Eur. Respir. J. 26: 319-338. Namazi S, Monabati A, Ardeshir-Rouhani-Fard S and Azarpira N (2010). Association of angiotensin I converting enzyme (insertion/deletion) and angiotensin II type 1 receptor (A1166C) polymorphisms with breast cancer prognostic factors in Iranian population. Mol. Carcinog. 49: 1022-1030.

Pabst S, Theis B, Gillissen A, Lennarz M, et al. (2009). Angiotensin-converting enzyme I/D polymorphism in chronic obstructive pulmonary disease. Eur. J. Med. Res. 4 (Suppl 14): 177-181.

Rigat B, Hubert C, Corvol P and Soubrier F (1992). PCR detection of the insertion/deletion polymorphism of the human angiotensin converting enzyme gene (DCP1) (dipeptidyl carboxypeptidase 1). Nucleic Acids Res. 20: 1433.

Selahaddin T, Birgul I, Tekin Y and Selda S (2010). Chronic Obstructive Pulmonary Disease and Paraoxonase-1 192 and 55 Gene Polymorphisms. Biotechnol. Biotechnol. 24: 1644-1647.

Tkacova R, Joppa P, Stancak B, Salagovic J, et al. (2005). The link between angiotensin-converting enzyme genotype and pulmonary artery pressure in patients with COPD. Wien. Klin. Wochenschr. 117: 210-214.

Ucar G, Yildirim Z, Ataol E, Erdogan Y, et al. (1997). Serum angiotensin converting enzyme activity in pulmonary diseases: correlation with lung function parameters. Life Sci. 61: 1075-1082.

Ueda S, Heeley RP, Lees KR, Elliott HL, et al. (1996). Mistyping of the human angiotensin-converting enzyme gene polymorphism: frequency, causes and possible methods to avoid errors in typing. J. Mol. Endocrinol. 17: 27-30.

Yakut T, Karkucak M, Ursavas A, Gulten T, et al. (2010). Lack of association of ACE gene I/D polymorphism with obstructive sleep apnea syndrome in Turkish patients. Genet. Mol. Res. 9: 734-738.

Yaren A, Turgut S, Kursunluoglu R, Oztop I, et al. (2006). Association between the polymorphism of the angiotensinconverting enzyme gene and tumor size of breast cancer in premenopausal patients. Tohoku J. Exp. Med. 210: 109116.

Yaren A, Turgut S, Kursunluoglu R, Oztop I, et al. (2007). Insertion/deletion polymorphism of the angiotensin I-converting enzyme gene in patients with breast cancer and effects on prognostic factors. J. Investig. Med. 55: 255-261.

Zhang X, Wang C, Dai H, Lin Y, et al. (2008). Association between angiotensin-converting enzyme gene polymorphisms and exercise performance in patients with COPD. Respirology 13: 683-688.

Zhang Y, He J, Deng Y, Zhang J, et al. (2011). The insertion/deletion (I/D) polymorphism in the angiotensin-converting enzyme gene and cancer risk: a meta-analysis. BMC Med. Genet. 12: 159. 